往時は，じん肺の治療はそれに合併した肺結核の治療 でありじん肺そのものの治療は単なる対症療法に甘ん じほとんぞあきらめられていた。しかし最近はじん肺

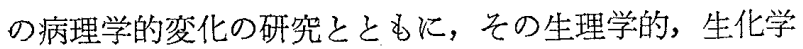
的病態が究明されるに至り，ようやく積極的な治療法が 考究され，一部に括いて実施されているが，一般には心 だ普及していないよらである。ここにその考え方と方法 の大略を述べて，大方の参考に供する。

じん肺は周知のごとく，吸入粉じんによる肺線維症で

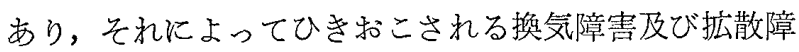
害であり，低酸素血症である。そして，これらの障害 （変化）が原因となり，肺気腫を特こし，肺循環障害よ り肺性心へと進展し, 加らるに気道感染, 全身萎縮へと 進展し，夺すす，その臨床像を複雑にしているのであ る。このような複雑多岐の病像を呈するじん肺症の治療 はきわめて困難な問題であり，線維化した肺組織を健全 な肺組織に修復することが最も根本的な㙩法であること は，議論の余地のないことではあるが，これは現代医学 の及ばざるところである。したがって，じん肺の治療は つぎの諸点詣向される。

1. 吸入した粉じんを再喀出させ, 線維化の原因を少 てでも除去する。

2. 線維化の進行を静止抑制する。

3. 気道の障害をできるだけ除去して，換気及び昖散 機能を回復させる。

4. 肺循環障害を除去して，肺性心への進展を抑制す る。

5. 低酸素血症を改善して，全身萎縮を防止し，体力 の維持につそめる。

以上飞対し，薬物並びに理学的方法をもって，綜合的 飞，積極的に治療することが大切であることを述べ，と くに低酸素血症改善については，一般の関心を喚起した w。

な抢，感染症の合併に対しては，強力に抗菌剤による 療法が必要である。とくに合併肺結核については，抗結 核剤による内科的療法が主体であるが，一般肺結核に比 して長期間を要し，じん肺の症度によって，その効果が 左右される傾向が叹らる。したがって，耐性を獲得す ることが多いので，耐性検查のもとに，抗結核剂の適正 な使用が必要である。また，空洞閉鎖はあまり望めない ので，有空洞例に対しては早期よりその対策を立てる必 要があり，時期を逸することなく，外科祭法に移すこと が必要である。外科療法としては，心肺機能の状態じ ん肺の種類, その進展度, とくに肺門部凂着の状態を検討
の上，腣葉切除術あるいは空洞切開術が行われている。 症例によっては，かなりの成果が望めるが，抗結核剂の 耐性如何に大きく左右されるので，施行の時期考察はゆ るがせにできない。

\section{5. 突業の塵肺および塺肺結核}

\section{松島 隆 (旭労災)}

梥業じん肺患者の，入院患者を主として治療経過を検 討した。

単純じん肺症中，穼業じん肺患者では，軽快14\%，不 変 $58 \%$ ，悪化 $28 \%$ となり，その他のじん肺患者では，軽 快 $6 \%$ ，不変 $33 \%$ ，悪化 $61 \%$ となり，悪化例が前者に比軟 して著明潧加している。軽快之山，自覚症状や心肺機 能の改善を意味するもので，X線所見の改善はほとんぞ ない。

これらの治療には，ATP，副婜皮質ホルモンや，肺 感染の場合は抗生物質を使用したが，IPPBによる薬液 の吸入も長期間実施した。弿業じん肺患者，との他のじ 几肺患者もともに，軽快例で怯全例飞 IPPBを実施し ているが，自他覚的症状の強い悪化例では，その約半数 しか施行できなかった。な技，各種の療法についても比 較検討した。

割業じん肺患者にも重症例が多く，各種の治療を実施 したにもかかわらず，死亡せるものが相当数あるが，そ の他のじん肺患者に比較すると，笘業けい肺では不変を 占める\%が大で，その進展には長期間要するととも に，悪化の程度も軽いのではないかと思われる。悪化の 誘因としては, 肺感染, 気管支拡張, 喘息, 自然気胸な ぞがあり，癌の合併をみたものもある。

じん肺結核の場合は, 胸部 X線所見, 検痰, 心肺機能, その他の臨床所見より，総合的診断により判定した。

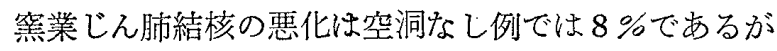
空洞例では20\%となり，その他のじん肺結核の昰化は， 空洞なし例で16\%であるが，空洞例では $38 \%$ で，何れの 場合も空洞例の悪化傾向が目立ち，また，梥業じん肺は その他のじん肺より悪化の程度が低い上う飞思われる。

空洞例の軽快例では，その約半数は外科手術によった ものである。じん肺結核の治療は，結核予防法に準じ て, 一次または二次抗結核剤を用いた。学研分類で, C 型，D型のもので排菌なく，その他の愁訴なき場合， IPPB 飞施行し, その他の治療は, 単純じん肺に準じ て行なった。 